\title{
FILOSOFIA E ENGAJAMENTO: \\ EM TORNO DAS CARTAS DA RUPTURA \\ ENTRE MERLEAU-PONTY E SARTRE
}

\section{MARILENA CHAUI}

Professora do Departamento de Filosofia FFLCH-USP

Nota: Em maio de 1995, o Centro Acadêmico de Filosofia "Prof. João Cruz Costa" realizou o Colóquio Sartre 90 anos, evento que diretamente marcava a posição do Centro de implementar o debate, contribuir para a formação dos estudantes de filosofia $e$, sobretudo, conjugar o acadêmico ao político em suas atividades. De lá para cá, outros colóquios e discussões seguiram os passos daquele evento, acentuando a mesma preocupação; com o que, de algum modo, se lhe reconheceu os erros mas também o acerto. $O$ texto que ora publicamos foi apresentado então em sua versão integral - ele aparecera parcialmente na Folha de São Paulo em 14 de agosto de 1994. O tema do texto, a difícil conjugação entre a Filosofia e a política, ainda é uma das preocupações maiores do Centro Acadêmico de Filosofia "Prof. João Cruz Costa"

"Reprovo-te, bem mais severamente, por abdicares, nas circunstâncias em que é preciso decidir como homem, como francês, como cidadão e como intelectual, usando tua 'filosofia' como álibi"

Primeira carta de Sartre

"Fiquei sabendo, lendo a revista [Les Temps Modernes], de tua posição atual sobre o PC [Partido Comunista Francês]. Isto valeu-me o ridículo [...] de te defender vivamente para saber, tardiamente, numa conversa, que tivemos apenas porque te pedi...que já não consideras válidas as obras que publicaste [...]. Eu não precisaria afastar a filosofia do mundo para permanecer filósofo - e nunca o fiz"

Resposta de Merleau-Ponty 


\section{O EPISÓdio e SUA CirCUNSTÂNCIA}

Três cartas assinalaram a ruptura entre Merleau-Ponty e Sartre, embora, como indica sua leitura, essa ruptura já viesse a caminho antes que a roca epistolar acontecesse. Essas cartas inserem-se entre os onze anos que vão da Liberação (1945) à invasão da Hungria pela URSS (1956).

Do ponto de vista das atividades e relações de ambos, esse período pode ser escandido em três tempos: o primeiro é imediatamente posterior à atividade política de Resistência no grupo criado por eles durante a guerra ("Socialismo e Liberdade"), à publicação de suas primeiras obras, sob o impacto da descoberta da fenomenologia de Husserl e da filosofia da existência de Heidegger, e à fundação da revista Les Temps Modernes (Sartre como diretor e Merleau como diretor político e editorialista) ${ }^{1}$; o segundo tempo é o do desentendimento e da ruptura, correspondendo, na obra de Merleau-Ponty aos textos sobre a transformação do marxismo em superstição pela ideologia dos partidos comunistas e sobre os campos de concentração na Rússia, bem como a aula inaugural no Collège de France (que seria publicada com o título Elogio da Filosofia), e, na de Sartre, à publicação da série de artigos de Os Comunistas e a Paz². O terceiro tempo, após a ruptura, corresponde ao restante da obra merleaupontyana (Merleau-Ponty morre em 1961) e, na sartreana (sem mencionarmos a imensa produção literária, teatral e política), aos ensaios preparatórios à publicação da Crítica da Razão Dialética (anunciada nas cartas com a menção de um livro sobre história, moral e política) ${ }^{3}$.

1 Obras de MERLEAU-PONTY, nesse primeiro período: $A$ Estrutura do Comportamento, Fenomenologia da Percepção, Senso e Não Senso, Humanismo e Terror, e a aula inaugural publicada como ensaio Elogio da Filosofia. Obras principais de SARTRE (a produção sartreana é enorme e muito diversificada): $O$ Ser e o Nada, O Imaginário, conjunto de contos reunidos em O Muro e a peça As Mãos Sujas.

2 Os textos da querela, vários deles publicados inicialmente em Les Temps Modernes, são: SARTRE, "Os Comunistas e a Paz"; LEFORT, "O marxismo e Sartre"; SARTRE, "Resposta a Lefort"; LEFORT, "Da resposta à questão"; MERLEAU-PONTY, "Filosofia e Política"(conferência que deveria ser o artigo censurado por Sartre), "Elogio da Filosofia", "Sartre e o ultrabolchevismo" Posteriores à ruptura, mas referidos a ela: MERLEAU-PONTY, prefácio de Sinais; SARTRE, necrológio de Merleau-Ponty "Merleau-Ponty vivo"; LEFORT, prefácio a Un Homme en Trop.

3 Obras de MERLEAU-PONTY: Sinais (cujo prefácio é um balanço crítico das questões políticas e filosóficas anteriores e posteriores à ruptura com Sartre), As Aventuras da Dialética, e a publicação, por Lefort dos capítulos e notas de trabalho do livro póstumo $O$ 
Politicamente, as cartas situam-se durante a época turbulenta da Quarta República francesa, entre novembro de 1945 (primeiro governo de De Gaulle, após a Liberação), e maio de 1958 (novo governo de De Gaulle, após a insurreição da Argélia). Marcada pelas lutas anticoloniais (Tunísia, Argélia, Indochina), a época vê o desmantelamento da Action Française, arregimentação católica fascista, e o crescimento da democracia cristã; e a numerosa presença da esquerda no parlamento, nos ministérios e nas prefeituras municipais, esquerda que passa da aliança com De Gaulle (vinda da Resistência) à oposição ao gaullismo. Este é responsável pelo fim da velha direita e pelo surgimento da moderna, com o conservadorismo liberal, a tecnocracia e o novo patronato. À direita, De Gaulle procura, contra ultraconservadores e comunistas, uma "terceira força", formada com liberais e cristãos; à esquerda, busca-se uma "terceira via", opondo-se ao comunismo, aos católicos de todos os matizes e ao americanismo.

No plano internacional, além das crises coloniais francesas, é o momento da discussão e implantação do Plano Marshall e do Pacto Atlântico, da guerra da Coréia, do macarthismo, da morte de Stálin e subida de Kruschev, com a primeira denúncia pública soviética do stalinismo. Entre 1950 e 1953 (ano das três cartas), teme-se uma terceira guerra mundial, prevalecendo na esquerda não-comunista uma atitude conhecida como "attentisme" ("espera") - aguardar a retomada do movimento operário revolucionário internacional, o recuo da ameaça de nova guerra, a reabertura de negociações com Ho Chi Min e, sobretudo, a espera de uma mudança na política internacional, reduzida, no momento, a táticas diplomáticas e militares.

Do ponto de vista cultural, é o momento do existencialismo ("a existência precede a essência", escreverá Sartre), com as idéias de subjetividade, situação, projeto, transcendência mundana e liberdade, e do marxismo, na versão dos intelectuais do Partido Comunista Francês. Saindo da paralisia imposta pela guerra, começa a retomada literária (com o romance existencialista de Sartre e Camus e o "nouveau roman"), teatral (com a presença do Théatre National Populaire - TNP - , o crescimento do festival de Avignon e da animação cultural de rua, em Paris e no interior) e cinematográfica

Visivel e o Invisível (mencionado na carta como Prosa do Mundo) e um conjunto de ensaios reunidos em dois volumes, Elogio da Filosofia e outros ensaios e A Prosa do mundo. 
visita do general Ridgway a Paris; para 4 de maio, convoca uma greve geral de repúdio à prisão do secretário geral do partido, Jacques Duclos, ocorrida durante a manifestação de abril. Nas duas ocasiões, os operários não respondem em massa à convocação.

De Roma, informado dos acontecimentos, Sartre escreve o primeiro artigo de Os Comunistas e a Paz, contra a prisão de Duclos, o anticomunismo e a fraca resposta operária ao chamamento do PCF Face ao anticomunismo, declara que, quando atacado, um partido comunista deve ser incondicionalmente defendido por todas as esquerdas. Face à fraca resposta do operariado francês ao PCF, Sartre parte da afirmação de Marx, no Manifesto Comunista, da necessidade do proletariado organizar-se num partido revolucionário e conclui que, sendo o Partido Comunista tal partido, sem ele os operários não existirão como classe, mas apenas como massa passiva e alienada. Identifica, assim, a história do proletariado e a ação dos partidos comunistas ou, como dirá Lefort ao criticar esse artigo, Sartre esquece a longa e difícil história dos movimentos operários em favor da autoimagem revolucionária de uma burocracia partidária que se coloca como representante exclusiva da classe.

Merleau-Ponty reage e pretende recusar a posição de Sartre publicando sob forma de artigo sua própria conferência sobre a relação entre filosofia e política, reforçando idéias que nela desenvolvera: a crise atual da idéia de revolução, a degenerescência do liberalismo, e a possibilidade de uma nova relação entre filosofia e política.

Por que há uma crise da idéia de revolução? indaga MerleauPonty. E responde: porque substituiu-se a idéia de Marx do desenvolvimento da consciência de classe pela idéia bolchevique de "interesses do partido" Merleau-Ponty enfatiza a diferença entre Marx e os PC's: enquanto o primeiro exigia uma práxis tecida nas mediações entre a subjetividade proletária e a objetividade das condições materiais históricas, os segundos praticam, a partir do bolchevismo, uma ação identificadora entre ambas, sem mediações. Essa concepção desemboca, afinal, na célebre distinção stalinista entre o "subjetivo" (a intenção pessoal isolada) e o "objetivo" (a ação segundo os interesses do partido), conduzindo à idéia totalitária de "correção-subjetiva-com-traição-objetiva", ou vice-versa, "correçãoobjetica-com-traição-subjetiva" (em suma, os critérios usados durante os Processos de Moscou). Já nessa conferência (significativamente anterior à mudança de atitude Sartre e à publicação de seu primeiro 
artigo sobre Os Comunistas e a Paz), Merleau-Ponty assinalava a coincidência entre o pensamento sartreano e a prática comunista, pois, tanto num caso como noutro, estão ausentes da idéia de práxis as mediações exigidas por Marx. A coincidência entre o anticomunista e o comunista decorria do fato de que Sartre jamais se dissera marxista - podendo por isso pensar sem a noção de mediações entre o objetivo e o subjetivo - e os comunistas haviam deixado de sê-lo. É essa coincidência, transformada por Sartre em filosofia, que levará Merleau-Ponty, na reelaboração da conferência em artigo, a falar em ultrabolchevismo sartreano.

Anticomunista confesso, Sartre, diante da violência cometida contra um comunista (a prisão de Duclos durante a manifestação de abril), pega da pena e, entre a cólera e a indignação, denuncia o fortalecimento da política reacionária e toma partido, ainda que não ingresse no Partido. Eis por que, simultaneamente, escreve um bilhete a Merleau-Ponty para avisá-lo de que, doravante, Les Temps Modernes admitirá "todas as tendências de esquerda", desde que estas considerem os problemas políticos como postos para todos os homens, não podendo ser escamoteados sob o pretexto de que seriam insolúveis, e considerem que um partido que obtém 5 a 6 milhões de votos, como o PCF, não pode ser excluído nem isolado. Com isso, julga Merleau-Ponty, desfigura-se o projeto de Les Temps Modernes e de uma esquerda não atrelada ao Partido Comunista.

Em julho de 1953, sob os efeitos do que se passava em Paris, Sartre escreve: "todo anticomunista é uma criatura desprezível, nada me fará mudar de opinião" Três anos depois, porém, sob o impacto da invasão soviética a Budapeste, escreverá: "jamais será possível reatar relações com os atuais dirigentes do PCF [...] resultado de trinta anos de mentiras e esclerose [...] Hoje, volto à oposição"

Nas cartas da querela que separará os amigos, Sartre cobra de Merleau-Ponty não engajar-se verdadeiramente. Merleau-Ponty cobra de Sartre a entrega a um engajamento às cegas, que o deixa ao sabor dos acontecimentos.

\section{O ENGAJAMENTO}

Um sentimento de profunda melancolia nos invade quando, rememorados hoje, os episódios que cercaram a ruptura entre Sartre e Merleau-Ponty aparecem sob a luz do irremediavelmente ultrapassado. Fosse maior a distância temporal, talvez esse 
sentimento não nos habitasse. Sua proximidade, porém, nos faz perceber o envelhecimento daquilo que, há pouco, apaixonava, reunia ou separava pessoas, decidia vidas e mortes, palavras e obras. No entanto, quando o tempo houver feito seu longo trabalho, nossos pósteros, certamente, não verão o velho, mas a dignidade do antigo.

Todavia, se assim é quanto aos fatos que originaram a polêmica e seu desenlace, o mesmo não pode ser dito das questões que a suscitaram, por que estas não foram ultrapassadas e constituem o solo no qual ainda (talvez sempre?) nos movemos. A primeira delas, a amizade, perpassa toda a história da filosofia, nas páginas extraordinárias de Platão, Aristóteles, Santo Agostinho, Boécio, La Boétie ou Montaigne. As três cartas que constituem a trama da ruptura exprimem a delicadeza do tecido da amizade, o cuidado recíproco dos dois tecelões para não esgarçá-lo nem rompê-lo e sua incapacidade para mantê-lo íntegro, pois, a cada novo fio trançado pelo avesso, algo se desfia no desenho do direito:

"Tu me falas de tua amizade. Que pena. Ouvi-te dizer que já não crês nas relações pessoais, só havendo relações de trabalho em comum. Como podes, senão por condescendência, falar de amizade no momento em que pões um fim a esse trabalho? Olhando para todos estes anos, vejo, de tua parte, muitos benefícios - quanto à amizade, não tenho tanta certeza. Para mim, ao contrário, não te reduzes à conduta que te vejo ter, não careces de incessantemente fazer 'por merecer' para que eu te assegure minha amizade" (Carta de MerleauPonty).

"Gostaria de ver-te para salvar nossa amizade e não para acabar de perdê-la, eis o que quero que saibas" (Carta de Sartre).

A força das paixões e a convicção de cada um dos protagonistas deixam suas marcas, como farrapos que mal encobrem sua nudez, mas que, se os dilacera, não os envergonha nem nos envergonha.

A segunda questão, atada momentaneamente à figura do "intelectual engajado", coloca um dos temas fundamentais que Sartre e Merleau-Ponty desenvolveram em suas obras: o da relação entre filosofia e política ou, na expressão de Merleau-Ponty, "as difíceis relações entre o filósofo e a Cidade" e, na de Sartre, "uma filosofia que se interesse pelos homens reais, com seus trabalhos e suas penas"

O leitor de hoje talvez não consiga avaliar o peso e a contundência que essas afirmações possuíam ontem, justamente 
porque aquilo que os dois filósofos buscavam realizou-se em suas obras e, agora, parece uma evidência adquirida, uma coisa ao alcance de nossa mão, um dado cultural instituído e uma significação sedimentada. Em suma, para nós já é tradição. Para eles, no entanto, o que diziam era uma filosofia por fazer, uma concepção da filosofia que exigia rupturas e criação, ou para usar um dos conceitos que tanto os ocupou, a filosofia como projeto e um projeto para a filosofia, situado entre duas recusas: a da filosofia universitária francesa, espiritualista e idealista, e a filosofia da história do Partido Comunista Francês, esclerosada pela cisão entre uma teoria idealista e uma práxis empirista, solidária com stalinismo e com a visão burocrática do pensamento e da ação - o que Merleau-Ponty iria chamar de "mecanicismo dialético" (um automatismo que se faz às nossas costas e à nossa revelia) e Sartre chamaria de "escolástica da totalidade" (um esquecimento de que o materialismo histórico é análise presente do presente).

Nas Questions de Méthode, distinguindo entre filosofia e ideologia para afirmar que o marxismo é a filosofia de nosso tempo que se manterá viva enquanto as condições históricas que a suscitaram permanecerem, Sartre apresenta o existencialismo, não o de Kierkgaard nem o de Jaspers, mas aquele que, como ideologia, "se desenvolveu à margem do marxismo e não contra ele", isto é, um pensamento parasitário por que depende do marxismo tanto para existir quanto para significar e que desaparecerá quando o marxismo também houver desaparecido. Ao mesmo tempo, o marxismo de que fala não é o dos comunistas nem o das burocracias partidárias que o transformaram em "escolástica da totalidade", em "idealismo voluntarista" que opera com essências a priori ou com entidades abstratas como se fossem tipos e não singularidades históricas concretas. A crítica da filosofia universitária depende do marxismo, assim como a crítica do comunismo depende do existencialismo, na medida em que este, como o marxismo, "aborda a experiência para nela descobrir sínteses concretas" Como era a filosofia universitária francesa?

“Quando eu tinha vinte anos, em 1925, não havia uma cátedra de marxismo na universidade e os estudantes comunistas evitavam recorrer ao marxismo ou mesmo nomeá-lo em suas dissertações; se o fizessem teriam sido reprovados em todos os exames. $O$ horror à dialética era tal que até mesmo Hegel era desconhecido. Claro que nos permitiam ler Marx e mesmo aconselhavam-nos a lê-lo: era preciso conhecê-lo 'para refutá-lo' Porém, sem a tradição hegeliana e sem 
professores marxistas, sem programa, sem instrumentos de pensamento, nossa geração, como as precedentes e a seguinte, ignorava tudo do materialismo histórico. Em contrapartida, ensinavam-nos minuciosamente a lógica aristotélica e a logística. Foi por essa época que li $O$ Capital e $A$ Ideologia Alemā: eu compreendia tudo luminosamente e não compreendia absolutamente nada. Compreender é mudar-se, ir além de si mesmo: essa leitura não me mudava. Em contrapartida, o que começava a me mudar era a realidade do marxismo, a pesada presença, no meu horizonte, das massas operárias, corpo enorme e sombrio que vivia o marxismo, que o praticava, e que à distância exercia uma atração irresistível sobre os intelectuais pequeno-burgueses [...] Repito: não era a idéia que nos transtornava, nem a condição operária da qual tínhamos um conhecimento abstrato e não a experiência. Não. $O$ que nos transtornava era uma ligada à outra, era, em nosso jargão de idealistas abandonando o idealismo, o proletariado como encarnação e veículo de uma idéia. Creio ser preciso completar a fórmula de Marx: quando a classe em ascensão toma uma consciência de si mesma, essa tomada de consciência age à distância sobre os intelectuais e desagrega as idéias em suas cabeças [...] Havíamos sido educados no humanismo burguês e esse humanismo otimista se esfacelava porque adivinhávamos, nos arredores de nossa cidade, a imensa massa de 'sub-homens conscientes de sua sub-humanidade', mas ainda sentíamos o esfacelamento de maneira idealista e individualista: os autores que amávamos, naquela época, nos diziam que a existência é um escândalo. Todavia, o que nos interessava eram os homens reais, com seus trabalhos e suas penas; exigíamos uma filosofia que desse conta de tudo sem nos apercebermos de que ela já existia e que era ela, justamente, que provocava em nós essa exigência."4

De modo semelhante, em "La Guerre a eu lieu", Merleau-Ponty descreve o esfacelamento do otimismo humanista universitário e da boa-consciência francesa, sob os efeitos da guerra que trouxe a evidência bruta e irrecusável do peso da história, da opacidade das relações sociais por que estas não são relações imediatas entre consciências, mas relações mediadas pelas coisas e pelas instituições. Os franceses foram surpreendidos com a guerra quando, no verão de 1939, pretendiam gozar as férias como sempre as haviam gozado, como se a invasão da Polônia não houvesse ocorrido, como se os discursos de Hitler se referissem a uma Alemanha distante, como se não existissem os embates entre os partidos alemães como expressão

"SARTRE, "Questions de Méthode" in Critique de la Raison Dialectique, Gallimard, Paris, 1960 , p. $22-23$ 
da luta de classes e como se o discurso da guerra não estivesse endereçado à Europa. Fomos surpreendidos, escreve Merleau-Ponty, por que "não nos guiávamos pelos fatos" $\mathrm{e}$ "havíamos secretamente decidido ignorar a violência e a infelicidade como elementos da história" Por que o abandono dos fatos e a ignorância da história? "Porque vivíamos num país muito feliz e muito fraco para encarálos" Na universidade, professores ensinavam que guerras nascem de mal-entendidos que podem ser dissipados ou de acasos que podem ser conjurados pela paciência e pela coragem:

“Convidavam-nos a colocar em dúvida a história já feita, a reencontrar o momento em que a guerra de Tróia poderia ainda não acontecer e no qual a liberdade, num só gesto, esfacelaria as fatalidades externas. Essa filosofia otimista, que reduzia a sociedade humana a uma soma de consciências sempre prontas para a paz e para a felicidade, era a filosofia de uma nação dificilmente vitoriosa, uma compensação imaginária, recordações de 1914. Sabíamos dos campos de concentração, que os judeus eram perseguidos, mas essas certezas pertenciam ao campo do pensamento. Não vivíamos em presença da crueldade e da morte, não estávamos postos diante da alternativa de sofrê-las ou enfrentá-las [...] Ao mesmo tempo que objeto de horror, o anti-semitismo nos aparecia como mistério e, formados pela filosofia que nos formara, todo dia, durante quatro anos, perguntávamos: como o anti-semitismo é possivel? Havia um único meio de evadir-se da questão: podia-se negar que o antisemitismo fosse verdadeiramente vivido por alguém." 5

Do mesmo modo, a "política cartesiana" dos intelectuais e professores, ou a política da liberdade das consciências individuais em seu solipsismo essencial, não era capaz de compreender o colaboracionismo nem a resistência. Quanto ao primeiro, colocou no mesmo plano chefes ou dirigentes e o povo, como se fosse a mesma coisa optar pela colaboração e não poder recusar trabalhar e prestar serviço aos ocupantes. Quanto à segunda, experimentou-a como "felicidade no perigo", como supressão do dilema entre o ser e o fazer, como vida clandestina tecida nas relações de homem a homem ou de consciência a consciência. Mas, por seu turno, os intelectuais do Partido Comunista Francês, certos de possuírem o segredo da história e da luta de classes, consideraram o nazi-fascismo uma crise do capitalismo e a guerra apenas uma aparência que não tocaria na

5 MERLEAU-PONTY, "La Guerre a eu lieu" in Sens et Non Sens, Nagel, Paris, 1965, p. 246 e251. 
solidariedade internacional do proletariado, em suma, elaboraram uma ideologia da guerra e da luta de classes que lhes permitia, pela aplicação mecânica da relação capital-trabalho, evitar uma análise materialista e histórica da guerra e da luta de classes. Subjetivismo abstrato cartesiano e objetivismo abstrato comunista, eis o ensinamento da guerra:

"A guerra e a ocupação não somente nos ensinaram que os valores permanecem nominais e nem mesmo valem sem uma infra-estrutura econômica e política que os faça entrar na existência. Mais do que isto: que, na história concreta, os valores nada mais são do que a maneira de designar as relações entre os homens tais como se estabelecem segundo o modo de seu trabalho, de seus amores, de suas esperanças, numa palavra, de sua coexistência [...] $\mathrm{Na}$ coexistência dos homens, para a qual estes anos nos despertaram, as morais, as doutrinas, os pensamentos e os costumes, as leis, os trabalhos, as palavras se exprimem uns aos outros, tudo significa tudo. Nada há fora dessa única fulguração da existência." 6

A guerra e a descoberta do marxismo operaram em Sartre e Merleau-Ponty como o despertar de um duplo sono dogmático: o do idealismo universitário e o do escolasticismo comunista. Nesta perspectiva, as três cartas de ruptura entre ambos ganham um sentido muito mais forte do que pareceria à primeira vista, pois Os Comunistas e a Paz (causa da polêmica e da divergência que iria aprofundar-se) aparecem para Merleau-Ponty como a negação do projeto filosófico no qual tanto ele quanto Sartre pareciam engajados desde a fundação de Les Temps Modernes. Por outro lado, compreende-se a reação de Sartre (e a de Simone de Beauvoir) quando, de um lado, Merleau-Ponty afirma o cartesianismo sartreano e, de outro lado, Lefort acusa o cripto-comunismo de Sartre.

Os Comunistas e a Paz indicam, para os amigos mais próximos, a mudança de opinião e de posição políticas por Sartre. Qual a mudança? Sartre passara do anticomunismo à defesa do comunismo e retornava ao anticomunismo, mas, agora, considerando-se marxista. Essa mudança, evidentemente, não era fruto de humores, manias ou fobias, nem falta de caráter. Na interpretação de MerleauPonty, ela se enraíza numa concepção da filosofia e da política que embora modificada bastante na Crítica da Razão Dialética, conserva-se ao longo das obras sartreanas, desde O Ser e o Nada. 
Partindo da fenomenologia husserliana e da filosofia heideggeriana da existência, a tese nuclear das primeiras obras de Sartre - O Ser e o Nada e O Imaginário - é a diferença de essência (em sentido fenomenológico) entre o mundo das coisas - o Ser - e a consciência - o Nada. O primeiro é substância, resistente, opaco e viscoso. É o em-si, a objetividade nua e bruta. A segunda, ao contrário, é insubstancial, não é alma ou psique, substância imaterial ou espiritual, mas pura atividade e espontaneidade. É o para-si, a subjetividade plena. Para ela, os outros, embora presumidos como humanos, são mundo, portanto, seres ou coisas. Opacos para a consciência, os outros a deixam no solipsismo como única existência possível. Donde a célebre expressão de Entre Quatro Paredes: "o inferno são os outros", pois cada um deles, enquanto consciência ou sujeito, reduz os demais à condição de mera coisa e é reduzido pelos outros à condição de coisa.

Embora situada no mundo, a consciência, por ser nada, não é condicionada por ele, não podendo ser determinada pelas coisas nem pelos fatos. Pelo contrário, tem o poder de nadificá-los, fazendo-os existir como idéias, imagens, sentimentos e ações. Donde a conhecida fórmula sartreana: "estamos condenados à liberdade" Não é casual que, logo após O Ser e o Nada, a obra seguinte de Sartre tenha sido justamente $O$ Imaginário, pois é na consciência imaginante que melhor se apreende $o$ poder nadificador da subjetividade. Compreende-se também porque, desde essas primeiras obras, apareça nas obras literárias sartreanas a idéia de que a política é decisão e escolha inteiramente livres, exprimindo-se noutra célebre frase sartreana: "o importante não é o que os outros fazem aos homens, mas o que eles fazem com o que quiseram fazer deles"

Para Merleau-Ponty, desde a Fenomenologia da Percepção (particularmente no capítulo dedicado à liberdade), o Nada sartreano é a nova versão da consciência de si reflexiva de Descartes depois de reformulada por Kant, Hegel e Husserl, portanto, soberana, fundadora, constituidora do sentido do Ser. É significativo que a $O$ Imaginário, do lado de Sartre, corresponda, do lado de Merleau-Ponty uma Fenomenologia da Percepção que acentua o mundo prépredicativo, pré-tético, no qual vivemos e de onde emergimos como intercoporeidade e intersubjetividade, portanto, atados ao tecido do mundo e aos outros, sem o poder para constitui-los. Essa diferença aparecerá no plano da política: na resposta à primeira carta de Sartre, Merleau-Ponty enfatiza o contraste entre a posição de Os Comunistas 
e a Paz sobre as condições objetivas na URSS $\mathrm{e}$ as análises merleaupontyanas dessas mesmas condições, realizadas em Humanismo e Terror, análises que haviam sido recusadas publicamente por Sartre "quando mencionava, não sem sarcasmos [...] os infelizes que vêem o social entre o em-si e o para-si", isto é, como tecido intersubjetivo mediado pelas instituições econômicas e políticas. Em suma, é a relação entre o subjetivo e o objetivo que separa os dois filósofos.

A filosofia de Merleau-Ponty, vinda das mesmas fontes que as de Sartre, ergue-se, porém, contra elas enquanto herdeiras do intelectualismo, isto é, da suposição da soberania da consciência como doadora de sentido e fundadora do mundo enquanto significação. A tradição intelectualista é a do pensamento de sobrevôo, isto é, de uma consciência que, situando-se fora do mundo e diante das coisas, os domina pelo pensamento. $\mathrm{Ou}$, como escreve o filósofo, faz a realidade existir como representação ou idéia, numa filosofia que passa do ver ao "pensamento de ver", do imaginar ao "pensamento de imaginar", do sentir ao "pensamento de sentir"

Contra a herança intelectualista, Merleau-Ponty afirma a encarnação da consciência num corpo cognoscente e reflexivo, dotado de interioridade e de sentido, relacionando-se com as coisas como corpos sensíveis também dotados de interioridade e de sentido. Nossa relação fundamental com o mundo é a da intercorporeidade, fundadora da intersubjetividade e fundada por ela numa troca e num cruzamento intermináveis: os outros não coisas nem partes da paisagem, são nossos semelhantes. Não é gratuito, portanto, que as primeiras obras de Merleau-Ponty estudem a estrutura do comportamento e a essência da percepção. $O$ pensamento começa e se faz nas relações de nossa vida encarnada com o mundo: a percepção e a linguagem. Se a consciência não é pura espontaneidade desencarnada soberana, compreende-se que a liberdade, na formulação merleaupontyana, seja "o poder para transcender a situação de fato, que não escolhemos, dando-lhe um sentido novo", como El Greco, que transforma seu astigmatismo em pintura, Valéry e Cézanne, sua melancolia em obra poética e pictórica, Proust, sua neurastenia em literatura, Marx, sua condição de advogado pequenoburguês em traidor de sua classe e revolucionário. Em lugar de uma explicação mecanicista que explica a obra pela vida e de uma explicação intelectualista que explica a vida pela obra, Merleau-Ponty fala numa obra "que exigia esta vida" Eis por que, em sua carta a 
Sartre, Merleau-Ponty insiste em que ser filósofo não pode, de modo algum, separar-se e afastar-se do mundo: não estamos no mundo (como queria Sartre ao falar em situação), mas somos do e com o mundo.

Quais as conseqüências políticas dessas duas concepções divergentes da filosofia? Exatamente o que transparece nas três cartas trocadas entre ambos: Sartre, pondo-se no turbilhão vertiginoso dos acontecimentos - o Nada à procura de Ser para transformá-lo no que a consciência pensa e quer -, Merleau-Ponty exigindo distanciamento - nossa promiscuidade originária com o mundo exige que a filosofia não seja submersa pelos fatos, nem o filósofo arrastado pela força dos acontecimentos. No prefácio de Sinais, Merleau-Ponty escreve: "em filosofia, o caminho pode ser difícil, mas temos certeza de que cada passo torna possível os outros. Em política, temos a impressão acabrunhante de que tudo deve ser sempre refeito"

Porque, para Sartre, a consciência é leve e insubstancial, pode aceitar o apelo de todos os fatos e de todos os acontecimentos: a consciência não se deixa impregnar por eles, conservando a soberania. É porque a consciência é encarnada num corpo e situada na intercorporeidade e na intersubjetividade que Merleau-Ponty não pode, para usarmos a expressão que emprega no Elogio da Filosofia ao definir o filósofo, "dar o assentimento imediato e direto a todas as coisas, sem considerandos", pois "é preciso ser capaz de tomar distância para ser capaz de um engajamento verdadeiro, que é sempre também um engajamento na verdade"

Referindo-se à aula inaugural de Merleau-Ponty no Collège de France, Sartre afirma que seu amigo possui uma concepção da filosofia que só aparentemente permitiria conciliá-la com a política, mas que, realmente, torna impossível "jogar nos dois tabuleiros" A política, escreve ele, é ação fundada numa escolha objetiva, a partir dos dados e fatos disponíveis. Se a filosofia for, como pretende Merleau-Ponty, a exigência de, antes de escolher, colocar-se num distanciamento que permita apreender totalidades parciais e não os fatos isolados que formam nossa experiência quotidiana, então, escreve Sartre, "um filósofo de hoje não pode tomar uma atitude política"

Que pretende Merleau-Ponty em julho de 1953? “Que é preciso saber o que é o regime soviético para escolher" a favor ou contra. 

Merleau-Ponty em todas as ocasiões urgentes impostas pela política e às quais não respondeu.

Ao que parece, responde Merleau-Ponty, eu teria renunciado à política por haver escolhido a filosofia, à semelhança de alguém que, entre várias profissões, escolheu a de alpinista. Não renunciei à política: recusei-me a conceber o engajamento nos mesmos termos em que o concebes. Como Sartre concebe o engajamento? O intelectual engajado sartreano é o escritor de atualidades que opina e intervém sobre todos os acontecimentos relevantes, à medida que vão se sucedendo uns aos outros. É um estado de vigilia permanente, contra a "sonolência sonhadora"

Merleau-Ponty recusa esse tipo engajamento. Dois motivos o afastam da vigília sartreana, em nome de uma outra vigilância. Em primeiro lugar, diz ele, porque, ao escrever em conta-gotas sobre cada acontecimento, o escritor induz o leitor a aceitar fatos isolados que recusaria se pudesse ter uma visão mais abrangente, ou, ao contrário, o induz a recusar como odiosos fatos isolados que, se percebesse de maneira mais abrangente, aceitaria. Essa vigília engajada é, afinal, má-fé. Não informa, não analisa, não reflete, corre e muda ao sabor dos eventos, de tal modo que se fosse dado ao leitor, um dia, reunir o conjunto de manifestos e pequenos artigos diários ou mensais de um intelectual engajado ou de um comentarista político perceberia a incoerência, a leviandade, a irresponsabilidade daquele que escreve:

"isso permitiria fazer engolir no varejo o que não seria aceitável no atacado, ou, ao contrário, em tornar odioso, a golpe de pequenos fatos verdadeiros, aquilo que, visto no conjunto, faz parte da lógica da luta"

O segundo motivo é espantoso. Com efeito, tendo apresentado o primeiro, seria de supor-se que Merleau-Ponty houvesse atacado Sartre por agir às cegas, manifestando-se em toda parte sobre todos os acontecimentos sem jamais possuir um conhecimento aproximado do todo ou, pelo menos, das linhas de força e vetores dos eventos, não lhes alcançando a significação. Ora, dá-se exatamente o contrário. É que, graças à soberania do Nada sobre o Ser, Sartre construiu, em pensamento e em imaginação, um futuro fixo, mantido em segredo, que regula clandestinamente o curso dos acontecimentos, aconteça $o$ que acontecer. Sartre possui o futuro e a história em pensamento e em imaginação, sendo-lhe fácil opinar sobre tudo e tomar posição em tudo. Em outras palavras, os acontecimentos são tidos como a 
política, pois está sob nossa responsabilidade compreender as mediações subjetivas e objetivas que orientarão o rumo dos acontecimentos. Manifestar-se sobre tudo, assumir posição e ter opinião sobre tudo, mudar de atitude conforme mudem os ventos, abandonar a obra já escrita, desdizendo-a e desdizendo-se, é irresponsabilidade, não é liberdade.

Sartre podia afirmar que sua obra já realizada deveria ser esquecida a cada nova circunstância. Julgava, com isto, demonstrar seu compromisso com a filosofia e a política. Merleau-Ponty, ao contrário, exigia de sua obra retomada contínua, constância para que as reformulações tivessem sentido e fizessem sentido. Sartre viveu a alegria inflamada da tomada de posição contínua. Merleau-Ponty, a exigência de um pensamento capaz de modificar-se sob a solicitação dos acontecimentos, mas jamais para satisfazê-los. Por isso, sabendo que perderia o amigo, escreveu-lhe:

"Quando se está muito seguro do futuro, não se está seguro do presente [...] Tens uma facilidade para construir e habitar o porvir que é toda tua. Ao contrário, vivo mais no presente, deixando-o indeciso e aberto, como ele é. Não significa que eu construa um outro porvir [...] Não é que eu seja um 'homem revoltado', e muito menos um herói. Minha relação com o tempo se faz sobretudo pelo presente, eis tudo"7.

Palavras que ecoarão no prefácio de Sinais, quando escrever:

“O mal não é criado por nós nem pelos outros, nasce do tecido que fiamos entre nós e que nos sufoca. Que novos homens, suficientemente duros, serão suficientemente pacientes para refazê-lo verdadeiramente? A conclusão não é a revolta, é a virtù sem qualquer resignação"

As relações do filósofo com a Cidade são difíceis porque ela lhe pede exatamente $o$ que ele não lhe pode dar: o assentimento imediato, sem maiores considerações. Sartre desejou que tais relações não fossem difíceis, empenhou-se para que o filósofo estivesse engajado por inteiro nos acontecimentos, mas, por isso mesmo, em sua coragem destemida, acabou cedendo às exigências cegas da Cidade, dando-lhe o que ela lhe pedia.

Se a polêmica com Sartre e a ruptura com o amigo repercutiu intensamente na obra de Merleau-Ponty, como transparece na 
publicação de As Aventuras da Dialética, no prefácio de Sinais, no capítulo sobre a dialética e a reflexão em $O$ Visível e o Invisível, se ao longo destes texto insiste na afirmação de que há um "mau casamento" entre a filosofia e a política quando a primeira, em nome da segunda, se faz má-fé, e a segunda, em nome da primeira, se torna abstração, não menos profundas são as marcas deixadas em Sartre e um dos melhores testemunhos disto encontra-se, justamente, na Crítica da Razão Dialética e em sua preparação, as Questões de Método. Em ambas, Sartre dedica-se à compreensão da necessidade das mediações que constituem as relações sociais e o tecido histórico e sem as quais a articulação entre teoria e prática não pode ser formulada, nem a alienação pode ser compreendida e, finalmente, sem a qual uma filosofia da liberdade torna-se impossível ou miragem idealista. Donde a importância, nas Questões de Método, do estudo das chamadas "disciplinas auxiliares" e da idéia de um método pregressivo-regressivo que dê substrato histórico à noção de projeto. Do mesmo modo, na Crítica da Razão Dialética, compreende-se o papel preponderante do conceito de trabalho e da teoria do grupo para a compreensão da idéia de classe social e da prática da luta de classes como motor da história. Mas é na resposta de Sartre a Lukács sobre a consciência de classe que, finalmente, ele julga responder à maior objeção filosófica que Merleau-Ponty lhe fizera, isto é, de haver permanecido no ponto de vista de uma filosofia da reflexão:

“O princípio metodológico que faz começar a certeza com a reflexão não contradiz de modo algum o princípio antropológico que define a pessoa concreta por sua materialidade. Para nós, a reflexão não se reduz à simples imanência do subjetivismo idealista: ela só é um ponto de partida se logo nos relança para o meio das coisas e dos homens no mundo. A única teoria do conhecimento que, hoje, pode ser válida é aquela que se funda nesta verdade da microfísica: o experimentador faz parte do sistema experimental. É a única que permite afastar toda ilusão idealista, a única que mostra o homem real no meio de um mundo real. Mas esse realismo implica necessariamente um ponto de partida reflexivo, isto é, que o desvendamento de uma situação se faz na e pela práxis que a muda. Não colocamos a tomada de consciência na fonte da ação, nela vemos um momento necessário da própria ação: a ação, no curso do cumprimento, dá a si mesma suas próprias luzes. Isso não impede que tais luzes apareçam na e pela tomada de consciência dos agentes, o que implica necessariamente que façamos uma teoria do conhecimento. Pelo contrário, a teoria do conhecimento permanece como o ponto fraco do marxismo [...] Somente quando se compreender 
que o conhecimento não é conhecimento de idéias, mas conhecimento prático das coisas, então se poderá suprimir a noção de reflexo como intermediário inútil e aberrante. Poderse-á, então, dar conta desse pensamento que se perde e se aliena no curso da ação para reencontra-se pela e na própria ação. Mas, que nome dar a essa negatividade situada como momento da práxis e como pura relação com as próprias coisas, senão o de consciência? Há duas maneiras de cair no idealismo: uma consiste em dissolver o real na subjetividade, a outra em negar toda subjetividade real em proveito da objetividade. A verdade é que a subjetividade não nem tudo nem nada, mas representa um momento do processo objetivo (o da interiorização da exterioridade) e esse momento se elimina sem cessar para de novo renascer [...] A consciência de classe não é a simples contradição vivida que caracteriza objetivamente a classe considerada: ela é essa contradição já ultrapassada pela práxis e, por isso mesmo, conservada e negada conjuntamente. É precisamente essa negatividade desvendadora, essa distância na proximidade imediata, que o existencialismo chama 'consciência de objeto' e 'consciência não tética de si' "9

Cremos não ser casual que, tendo feito trajetórias tão diferentes, mas tendo como horizonte a recusa do idealismo filosófico e do positivismo científico, assim como o mecanicismo, o empirismo e o idealismo dos comunistas, Sartre e Merleau-Ponty se vissem confrontados não só com o problema da subjetividade, da objetividade e da intersubjetividade, como também com o da temporalidade e o da história e, portanto, com a questão da necessidade e da contingência, isto é, da liberdade. Vimos que Merleau-Ponty, na Phénoménologie de la Perception propusera compreender a liberdade como ultrapassamento das condições fatuais por uma significação que lhes dá um novo sentido e indica como a obra explica a necessidade desta vida determinada, e não o contrário. Não surpreende, então, encontrarmos em Sartre a noção do sentido como ultrapassamento ao qual, finalmente, dá o nome de liberdade:

"O homem constrói signos porque ele é significante em sua própria realidade e é significante porque é o ultrapassamento dialético de tudo o que é simplesmente dado. O que chamamos de liberdade é a irredutibilidade da ordem cultural à ordem natural."10

9 SARTRE, “Questions de... ", in Critique de la Raison Dialectique, op. cit., pp. 30-31

10 Idem, Ib., p. 96 
Para Merleau-Ponty, no entanto, mesmo nessa derradeira posição Sartre não teria ultrapassado o dilema do em si e do para si, da coisa e da consciência, do objetivo e do subjetivo. As palavras finais da Fenomenologia da Percepção nos deixam ver que, muito antes que se consumasse a ruptura entre os dois filósofos e amigos, ela já estava tacitamente posta:

“Nossa liberdade, dizem, ou é total ou é nula. Esse dilema é o do pensamento objetivo e da análise reflexiva, sua cúmplice [...] Estamos misturados com o mundo e com os outros de maneira indeslindável. A idéia de situação exclui a liberdade absoluta na origem de nossos engajamentos. E a exclui igualmente no ponto de chegada. Nenhum engajamento (nem mesmo o engajamento no Estado hegeliano) pode fazer-me ultrapassar todas as diferenças e tornar-me livre para tudo [...] Sou uma estrutura psicológica e histórica. Recebi com a existência uma maneira de existir, um estilo. Todas as minhas ações e meus pensamentos estão em relação com essa estrutura e até mesmo o pensamento de um filósofo nada mais é do que uma maneira de explicitar sua pegada sobre o mundo, aquele que ele é. E, no entanto, sou livre. Não a despeito ou aquém dessas motivações, mas por meio delas [...] Essa vida significante, essa certa significação da natureza e da história que sou não limitam meu acesso ao mundo; pelo contrário, são meu meio de comunicar-me com ele [...] Quer se trate das coisas ou das situações históricas, a filosofia não tem outra função senão a de nos reensinar a vê-las bem, e é verdade dizer que ela se realiza destruindo-se como filosofia separada."11

${ }^{11}$ MERLEAU-PONTY, Phénoménologie de la Perception, Paris, Gallimard, 1945, p. 520 